\title{
Description of Laboratory-Reared First Zoea of Luniella spinipes (Heller, 1861) (Brachyura: Xanthidae Chlorodiellinae) Collected from the Central Red Sea, Saudi Arabia
}

\author{
Ahmed E. Al Haj ${ }^{1,2}$ and Ali M. Al-Aidaroos ${ }^{1}$ \\ ${ }^{1}$ Department of Marine Biology, Faculty of Marine Sciences, King Abdulaziz University, P.O. Box \\ 80207, Jeddah 21589, Saudi Arabia \\ ${ }^{2}$ Department of Marine Biology, Faculty of environment Sciences and Marine Biology, Hadramout \\ University of Sciences and Technology, Yemen \\ a302378@gmail.com
}

\begin{abstract}
Ovigerous females of the Luniella spinipes was collected from Obhur Creek, central Red Sea. The larvae hatched under laboratory conditions. The larvae of L. spinipes is related to its congener Pilodius sp. larvae and can be distinguished by: the presence of small spines in ventral margin of carapace (vs. absent) and 5 setae in distal segment of second maxilliped (vs. 6 setae). The previous description of the first zoea of L. spinipes is incomplete and overlooked the small setation of antennule, spines endopod, setation of coxal basal and endopod endite of maxilla, first and second maxilliped, and posterodorsal setae of abdomen. In present study, first zoeal stages of L. spinipes was dissected, carefully re-examined and redescribed with illustrations. The first zoeal stages collected from the Saudi Arabian coast (central Red Sea) was differ from Al Ghardaqa (northern Red Sea). The second zoeal stage of L. spinipes was described for the first time and compared with those of the same larval stage of Pilodius nigrocrintus and Chlorodiella nigra. Keywords: Luniella spinipes, First zoea, Second zoea, Pilodius, Red Sea.
\end{abstract}

\section{Introduction}

Ten genera including 48 species are known of the family Chlorodiellinae ( $\mathrm{Ng}$ et al., 2008; Mendoza and Manuel-Santos 2012; Lasley et al., 2013, 2015). One new genera were established recently by Lasley and $\mathrm{Ng}$ (2015) namely Luniella Lasley, Kaus and $\mathrm{Ng}, 2015$ with 4 species worldwide. The newly formed genus Luniella has two species recorded in the Red Sea: L. pugil Dana, 1852 and L. spinipes Heller, 1861 (Serène, 1984; Vine, 1986). Luniella species crabs live under stones adjacent to reefs (Lasley et al., 2013, 2015). The first zoeas of around 7 species belonging to 4 genera of
Chlorodiellinae were morphologically described: Chlorodiella nigra (as Chlorodiella niger) by Gurney, 1938; Prasad and Tampi, 1957; Gohar and Al-Kholy, 1957), Cyclodius obscures (as Phymodius monticulosus) by $\mathrm{Ng}$ and Clark, 2000; L. spinipes (as Chlorodopsis spinipes) by Gurney, 1938; Pilodius nigrocrintus Stimpson 1858 (Terada, 1982; Ko and Lee, 2012); P. areolatus; L. pugil (as Pilodius pugil) by $\mathrm{Ng}$ and Clark, 2000 and Cyclodius paumotensis Rathbun 1907 (as P. paumotensis by Clark and Paula, 2003). Tow genera of family Chlorodiellinae (i.e. Pilodius and Luniella) have similar setotaxy (Clark, 2009). From Chlorodiellinae, the complete larval developments of Pilodius 
nigrocrintus (Terada, 1982) and Chlorodiella nigra (Gohar and Al-Kholy, 1957) were obtained in laboratories and morphologically described. In this paper, the first and second zoeal stages of Luniella spinipes were illustrated and described.

\section{Materials and Methods}

The berried females of Luniella spinipes was collected by hand from the rocks found in shallow water on $25^{\text {th }}$ October 2015 from

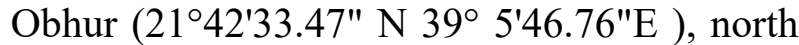
to Jeddah, central Red Sea. The female was reared under laboratory conditions, and around 150 larvae hatched on $27^{\text {th }}$ of October. Two batches of 50 larvae were reared in 1-litre containers with $800 \mathrm{ml}$ seawater with a salinity of $35 \%$ at $28{ }^{\circ} \mathrm{C}$ and 12 hours dark and light photoperiod.

The first and second zoeal stages were fed with rotifers. Water was changed every day. Ten larvae from each specimen were preserved in $70 \%$ ethanol for measurements and dissection. The larvae were dissected in lactophenol using Wild Stereo microscope. Setal counts were taken from proximal to distal portions. For zoeal stage, CW: distance between the tips of the lateral spines; CL: distance from the base of the rostral spine to the posterior margin of the carapace; TT: distance between the tips of dorsal and rostral spines. For the megalopa: $\mathrm{CW}$ : maximum distance across the carapace; CL: maximum distance along the carapace. Setal counts were made from proximal to distal portions. Setal numbers were represented for appendages from basis to endopod (Clark et al., 1998). The antennal exopod ratio to protopod length was measured from exopod base to its tip without the setae. The female crab and the un-dissected zoeas were deposited in the King Abdulaziz University Marine Museum (KAUMM-675).

\section{Results}

Only two zoeal stages were obtained, of which second stage was described for the first time in this present study.

\section{First Zoea (Fig. 1 A-M)}

Size (average \pm SD) T T $=0.9 \pm 0.03 \mathrm{~mm}, \mathrm{C}$ $\mathrm{W}=0.45 \pm 0.01 \mathrm{~mm}, \mathrm{C} \mathrm{L}=0.7 \pm 0.01 \mathrm{~mm}$.

Carapace (Fig. 1 A-D): dorsal spine long, straight and curved distally with many small spines; rostral spine straight, shorter than dorsal spine and protopod of antenna, with three small spines on surface; lateral spines straight and short. Anterodorsal surface without spine, ventral margin with minute spines and a pair of postrodorsal setae; eyes sessile.

Antennule (Fig. 1 E): Uniramous, endopod absent; exopod unsegmented with 4 broad and long aesthetascs, plus slender terminal seta.

Antenna (Fig. 1 F): Protopod distally multispinulate and longer than rostral spine; endopod present as small spine; exopod small, robust, $11 \%$ length of protopod with 2 short terminal setae.

Maxillule (Fig. 1 G): Coxal endite with 7 plumodenticulate setae; basal endite with 5 (2 cuspidate and 3 plumodenticulate) setae; endopod 2-segmented, proximal segment with simple seta, distal segment with 6 plumose $(2$ subterminal, 4 terminal) setae; exopod seta absent.

Maxilla (Fig. $1 \mathrm{H}$ ): Coxal endite bilobed with 4+4 plumodenticulate setae; basal endite with $5+4$ setation, endopod unsegmented, bilobed with $3+5 \quad(2$ subterminal, 3 terminal) plumodenticulate setae; Exopod (scaphognathite) margin with 4 plumose setae, one long stout distal process.

First maxilliped (Fig. 1 I): Coxal seta absent, basis with 10 medial simple setae arranged $2+2+3+3$; endopod 5-segmented with 3, 2, 1, 2 (plumose), 1(simple subterminal) +4 
(plumodenticulate terminal) setae respectively; exopod 2-segmented, distal segment with 4 long terminal plumose natatory setae.

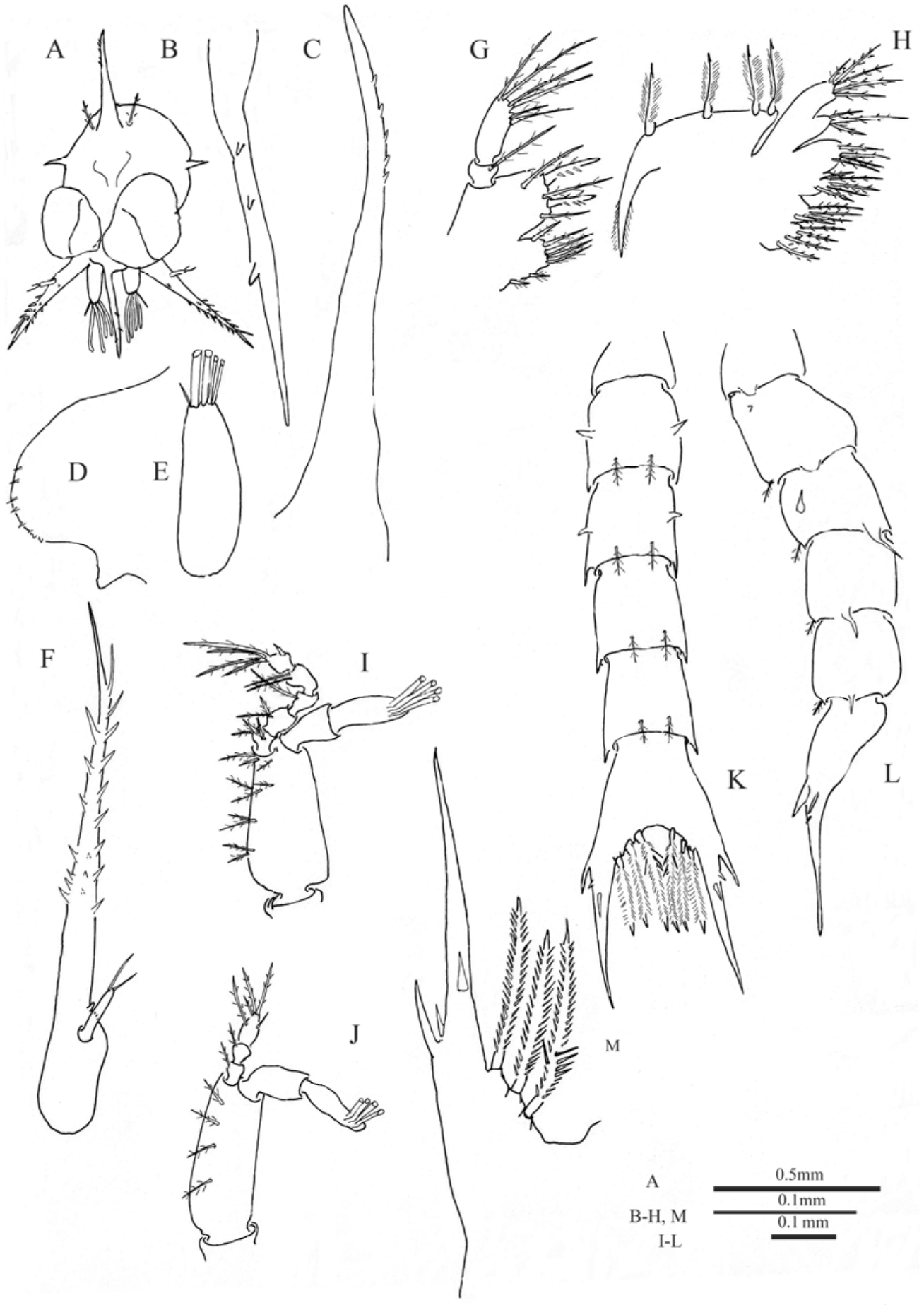


Fig. 1. The first zoea of Luniella spinipes, A. Carapace, B. Dorsal spine, C. Rostral spine, D. Ventra margin of carapace, E. Antennule, F. Antenna, , G. Maxillule, H. Maxilla, I. First maxilliped, J. Second maxilliped, K. Dorsal view of abdomen L. Lateral view of abdomen,, M. Dorsal view of telson.

Second maxilliped (Fig. 1 J): coxal seta absent; basis with 4 medial simple setae arranged $1+1+1+1$; endopod 3 -segmented with 1,1 (plumose), 5 (1 longer plumodenticulate, 1 shorter plumose subterminal, and 1 shorter and 2 longer plumodenticulate terminal) setae. Exopod 2-segmented, distal segment with 4 long terminal plumose natatory setae.

Abdomen (Fig. $1 \mathrm{~K}-\mathrm{L}$ ): 5 somites; first somite naked; second somite with a pair of dorsolateral processes directed anteriorly, third somite with a pair of dorsolateral processes directed posteriorly; first and second somite with rounded posterolateral process; second to fifth somites with 1 pair of posterodorsal setae; third to fifth somites with short posterolateral spinous processes.

Telson (Fig. $1 \mathrm{M}$ ): each fork with 2 pairs lateral spines (1 long, 1 small) and 1 pair dorsal medial spines, gradually curved distally, anterolateral spine considerably longer; inner margin with 3 pairs of stout spinulate setae.

\section{Second Zoea (Fig. 2 A-K)}

Size (average \pm SD) $\mathrm{T} \mathrm{T}=1.2 \pm 0.03 \mathrm{~mm}, \mathrm{C}$ $\mathrm{W}=0.6 \pm 0.01 \mathrm{~mm}, \mathrm{C} \mathrm{L} .=0.7 \pm 0.01 \mathrm{~mm}$.

Carapace (Fig. 2 A-B): eyes stalked; other characters unchanged.

Antennule (Fig. 2 C): exopod unsegmented with 6 broad and long aesthetascs, plus slender terminal seta.

Antenna (Fig. 2 D): exopod ratio protopod length ca. $9.9 \%$.

Maxillule (Fig. 2 E): epipod seta present, coxal endite with 8 plumodenticulate setae and a small bud; other characters unchanged.

Maxilla (Fig. 2 F): exopod (scaphognathite) margin with 11 plumose setae, stout process no longer prominent; other characters unchanged.
First maxilliped (Fig. 2 G): exopod 2segmented, distal segment with 6 long terminal plumose natatory setae.

Second maxilliped (Fig. $2 \mathrm{H}$ ): endopod 3segmented with 1, 1 (plumose), 6 (1 longer plumodenticulate, 2 shorter plumose subterminal, and 1 shorter and 2 longer plumodenticulate terminal) setae. Exopod 2segmented, distal segment with 6 long terminal plumose natatory setae. Other characters unchanged.

Pereiopods: absent.

Abdomen (Fig. 2 I-J): first somite with 1 dorsal medial seta; other characters unchanged.

Telson (Fig. $2 \mathrm{~K}$ ): inner margin with 3 pairs of stout spinulate setae plus a pair of small setae; other characters unchanged.

\section{Discussion}

Xanthidae larvae were divided to seven groups based on the characters of antenna and some other appendages (Rice, 1980; Martin, 1984; Fransozo et al., 1991). Of these groups, the larvae of Chlorodiinae were included to group I (Table 1). Recently, Clark and Cuesta (2015) modified the exopod armature description of Martin's group (I) as "protopod distally multispinulate, antennal exopod reduced to less than quarter of protopodal length and never armed with more than three setae". Until now, the first zoea of few species of Pilodius and Luniella were described (Table1): Luniella spinipes (Gurney, 1938 as Pilodius spinipes; the present study); L. pugil ( $\mathrm{Ng}$ and Clark 2000 as Pilodius pugil), P. nigrocrintus (by Terada, 1983; Ko and Lee, 2012) and P. areolatus (by $\mathrm{Ng}$ and Clark, 2000).

Some authors overlooked the presence of small spines on the ventral margin of carapace, 
coxal, basal and endopod endites of maxilla and posterodorsal setae of the abdomen and these spines were observed when the same species was re-described ( $\mathrm{Ng}$ and Clark, 2000; Clark, 2009; Tanaka and Konishi, 2001, 2009; Tanaka et al., 2010; Clark and Cuesta, 2015).
These spines were probably overlooked by Gurney (1938), while describing the zoeas of Luniella spinipes (Chlorodopsis spinipes) from the Red Sea, and in the present study, these spines overlooked by Gurney (1938) were observed and described.

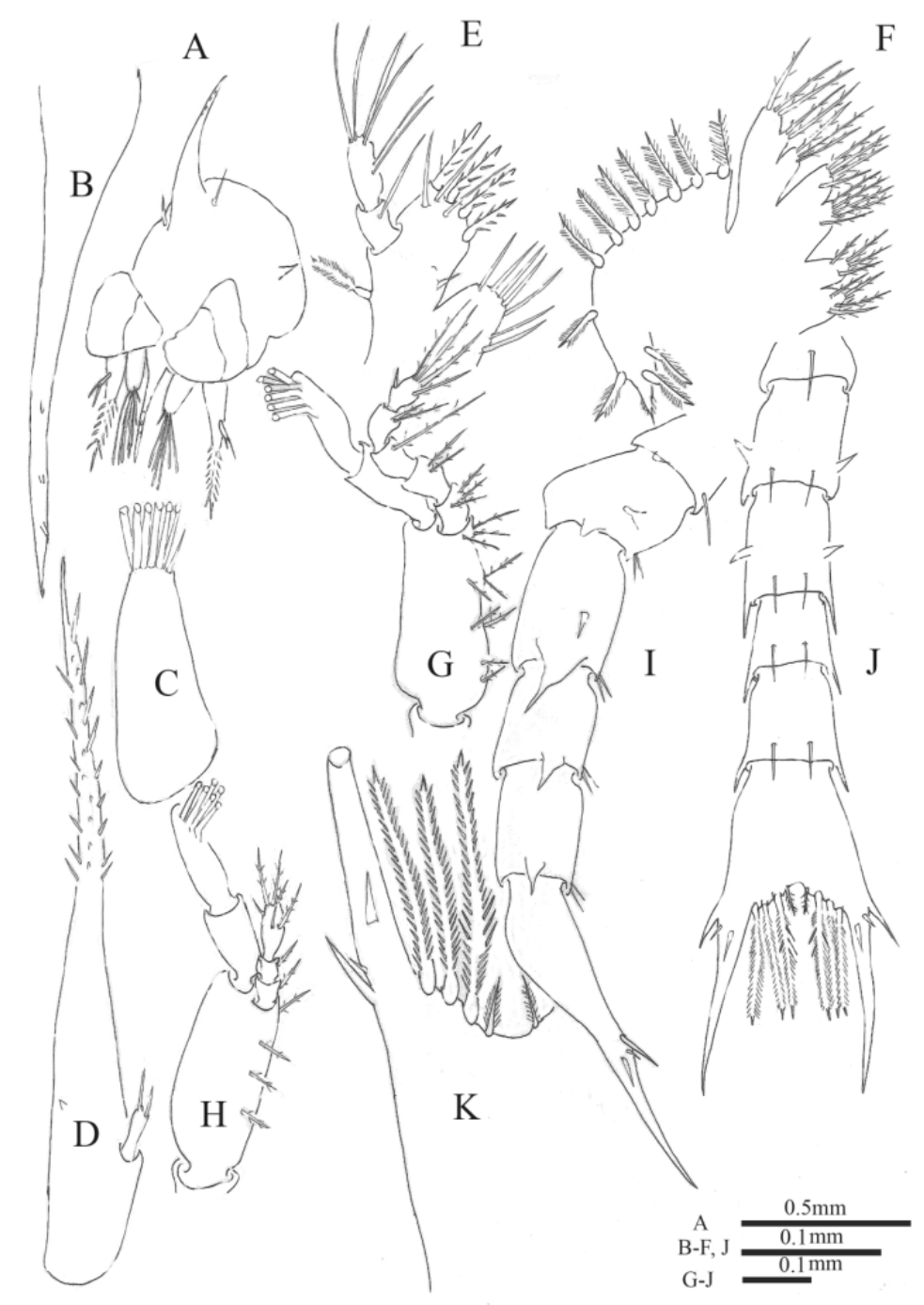

Fig. 2. The second zoea of Luniella spinipes, A. Carapace, B. Rostral spine, C. Antennule, D. Antenna, E. Maxilla, F. Maxillule, G. First maxilliped, H. Second maxilliped, I. Dorsal view of abdomen, J. Lateral view of abdomen, K. Dorsal view of telson.

Several differences are found between the $L$. spinipes of the present study and that of Gurney (1938) described from the Red Sea: ratio of the exopod to protopod, the setations of coxa, basis and endopod of maxilla, and the posterodorsal setations of abdomen (Table 1). In general, the first zoeal stages of $L$. spinipes in this present study are agree with L. pugil and Pilodius areolatus ( $\mathrm{Ng}$ and Clark, 2000). The 3.5 seta of distal segment of endopod of 
second maxilliped of the first zoea was present (6 setae) in L. pugil and P. areolatus described by $\mathrm{Ng}$ and Clark (2000) and P. nigrocrintus by
Terada (1982); Ko and Lee (2012), while it was absent ( 5 setae) in $L$. spinipes described in this present study and by Gurney (1938).

Table 1. Differences between the known first zoeas of Pilodius and Luniella species.

\begin{tabular}{|c|c|c|c|c|c|}
\hline Species & Pilodius areolatus & Luniella pugil & Luniella spinipes & $\begin{array}{l}\begin{array}{l}\text { Luniella } \\
\text { spinipes }\end{array} \\
\end{array}$ & $\begin{array}{c}\text { Pilodius } \\
\text { nigrocrinitus }\end{array}$ \\
\hline Authors & Ng \& Clark, 2000 & Ng \& Clark 2000 & Gurney, 1938 & Present study & Terada, 1982 \\
\hline \multicolumn{6}{|l|}{ Carapace } \\
\hline Ventral edge & Smooth & Smooth & Smooth & spinulate & Smooth \\
\hline Rs. to Pr. & Equal & Equal & Shorter & shorter & Equal \\
\hline \multicolumn{6}{|l|}{ Antennule } \\
\hline Aesthetascs & 4 & 4 & $\mathrm{Nd}$ & 4 & 3 \\
\hline Setae & 1 & 1 & $\mathrm{Nd}$ & 1 & 1 \\
\hline \multicolumn{6}{|l|}{ Antenna } \\
\hline Exe. \% & $10.4 \%$ & $8.9 \%$ & 7. $7 \%$ & $11 \%$ & $10 \%$ \\
\hline Endopod & Present & present & Absent & present & Present \\
\hline \multicolumn{6}{|l|}{ Maxilla } \\
\hline Coxa & $4+4$ & $4+4$ & $4+3$ & $4+4$ & $4+4$ \\
\hline Basis & $5+4$ & $5+4$ & $4+4$ & $5+4$ & $5+4$ \\
\hline \multicolumn{6}{|l|}{ Maxillule } \\
\hline \multicolumn{6}{|l|}{ Maxilliped I } \\
\hline Basis & $2,2,3,3$ & $2,2,3,3$ & $\mathrm{Nd}$ & $2,2,3,3$ & $2,2,3,3$ \\
\hline Endopod & $3,2,1,2,5$ & $3,2,1,2,5$ & $\mathrm{Nd}$ & $3,2,1,2,5$ & $3,2,1,2,5$ \\
\hline Maxilliped II & & & & & \\
\hline Endopod & $1,1,6$ & $1,1,6$ & $1,1,5$ & $1,1,5$ & $1,1,6$ \\
\hline Posterodorsal setae & Seg. 2-5 & Seg. 2-5 & Seg. 3-5 & Seg. $2-5$ & Seg. $2-5$ \\
\hline
\end{tabular}

Abbreviation: $\mathrm{Exe} \%=$ ratio of the length of antennal exopod to its protopod; $\mathrm{Nd}=$ no data; Rs. to Prt. =length of rostral spine to protopod of antenna; Schph. $=$ scaphognathite; Seg. $=$ segment.

Table 2. Differences between the second zoeal stages of Chlorodiellinae.

\begin{tabular}{|c|c|c|c|c|}
\hline \multicolumn{2}{|l|}{ Species } & \multirow{2}{*}{$\begin{array}{c}\begin{array}{c}\text { Luniella } \\
\text { spinipes }\end{array} \\
\text { Present study } \\
\end{array}$} & \multirow{2}{*}{$\begin{array}{c}\begin{array}{c}\text { Pilodius } \\
\text { nigrocrinitus }\end{array} \\
\text { Terada, } 1982 \\
\end{array}$} & \multirow{2}{*}{$\begin{array}{c}\text { Chlorodilla nigra } \\
\text { Gohar and Al-Kholy, } 1957 \\
\end{array}$} \\
\hline Authors & & & & \\
\hline \multirow[t]{3}{*}{ Carapace } & Ventral edge & Spinulate & Smooth & Smooth \\
\hline & $\begin{array}{l}\text { Rostral spine to } \\
\text { Protopod. }\end{array}$ & Shorter & Equal & Equal \\
\hline & Dorsal spine. & Spinulate & Smooth & Smooth \\
\hline \multirow{2}{*}{ Antennule } & Aesthetascs & 6 & 4 & 3 \\
\hline & Setae & 1 & 2 & 0 \\
\hline \multirow[t]{3}{*}{ Antenna } & Exopod. \% & $9 \%$ & $6 \%$ & $25 \%$ \\
\hline & Exopod & 2 & 2 & 3 \\
\hline & Endopod & present & Present & Absent \\
\hline \multirow[t]{4}{*}{ Maxilla } & Coxa & $4+4$ & $4+4$ & $3+2$ \\
\hline & Basal & $5+4$ & $5+4$ & $4+2$ \\
\hline & Endopod & $3+5$ & $3+5$ & $3+4$ \\
\hline & Scaph. & 12 & 12 & 6 \\
\hline \multirow[t]{4}{*}{ Maxillule } & Coxa & 7 & 8 & 4 \\
\hline & Basal & 8 & 9 & 10 \\
\hline & Endopod & 1,6 & 1,6 & 1,5 \\
\hline & Epipod & present & Present & absent \\
\hline \multirow[t]{2}{*}{ Maxilliped I } & Basis & $2,2,3,3$ & $2,2,3,3$ & $1,1,1,1$ \\
\hline & Endopod & $3,2,1,2,5$ & $3,2,1,2,5$ & $1,0,0,2,4$ \\
\hline \multirow[t]{3}{*}{ Maxilliped II } & Coxa & 0 & 0 & 0 \\
\hline & Basis & $1,1,1,1$ & $1,1,1,1$ & 0 \\
\hline & Endopod & $1,1,6$ & $1,1,6$ & $1 \mathrm{seg} .3$ \\
\hline
\end{tabular}




\begin{tabular}{llccc}
\hline & Exopod & 0,7 & 0,7 & 6 \\
Pereiopods & & absent & developed & absent \\
Abdomen & Segments & 5 & 6 & 5 \\
& Pelopopd & absent & present & Absent \\
Telson & Outer setae & 3 & 3 & 1 \\
\hline
\end{tabular}

Abbreviation: Exopod\%= ratio of the length of antennal exopod to its protopod; seg= segment.

The third endopod segment of the first maxilliped was naked in the first zoea of $C$. nigera described by Gohar and Al-Kholy (1957). This character was found in some species of Leucosiidae (Al Haj, 2012; Al Aidaroos et al., 2015) and Portunidae (Clark, 2009), but not observed in Xanthidae (Ko and Clark, 2002). The second zoea of the $L$. spinipes of the present study can be easily distinguished from the second zoeal stage of $P$. nigrocrinitus (Terada, 1982) and C. nigra (Gohar and Al-Kholy, 1957). In L. spinipes, the ventral margin and dorsal spine of carapace (spinulate vs. smooth), length of rostral spine to protopod antennule (shorter vs. equal), numbers of aesthetics setae of antennule (7 vs. 3-6) and ratio of exopod antenna to protopod length (9\% vs. 6-2.5\%) which are totally different from others (Table $2)$. In $P$. nigrocrinitus and $L$. spinipes, the setations of the maxilla, maxillule, first and second maxilliped and outer setae of telson are more different with $C$. nigra (Table 2). In $P$. nigrocrinitus (Terada, 1982), the pereiopods, pleopods and the sixth segment of abdomen are presence, whereas, in C. nigra (Gohar and Al-Kholy, 1957) and $L$. spinipes these appendages are absent.

\section{Acknowledgements}

This publication is dedicated to Michael Türkay, who sadly passed away. We would like to thank the team of the Red Sea Biodiversity Surveys in 2012 and 2013 for their help with sampling.The scientific research cooperation between King Abdulaziz University (KAU), Faculty of Marine Sciences (FMS), Jeddah, Saudi Arabia, and the Senckenberg Research Institute (SRI), Frankfurt, Germany, in the framework of the
Red Sea Biodiversity Project, during which the present material was collected, was funded by KAU GRANT NO. "I/1/432-DSR". The authors acknowledge, with thanks, KAU and SRI for technical and financial support.

\section{References}

Al Aidaroos, A.M.; Al Haj, A.E. and Türkay, M. (2015) Zoeal stages of Hiplyra variegata (Rüppell, 1830) (Crustacea: Brachyura: Leucosiidae) reared in the laboratory and collected from plankton at Al-Kharrar creek, central Red Sea, Journal of Natural History, DOI: 10.1080/ 00222933.2015.1079656

Al Haj, A.E. (2012) Seasonal variations of brachyuran larvae from Al-Kharrar Creek, the central Red Sea. A thesis submitted for the obtainment of M. Sc. degree, King Abdulaziz University, p. 267.

Clark, P.F. (2009) The bearing of larval morphology on brachyuran phylogeny. In: Martin, J.W., Crandall, K.A., Darryl, F.L., (Eds.), Decapod Crustacean Phylogenetics. Crustaceans Issues CRC/Taylor and Francis, ISBN: 9781420092588 .

Clark, P.F. and Ng, P.K.L. (1998) The larval development of the poisonous reef crab, Lophozozymus pictor (Fabricius, 1798) (Crustacea: Decapoda: Brachyura: Xanthidae: Zosiminae) with comments on femalial characters for first stage zoea. Zoosystema, 20 (2):201-220.

Clark, P.F. and Paula, J. (2003) Description of ten Xanthoidean (Crustacea: Decapoda: Brachyura) . first stage zoeas from Inhaca Island, Mozambique. The Raffles Bulletin of Zoology, 51 (2):323-378 .

Clark, P.F. and Cuesta, J.A. (2015) Larval systematics of the Brachyura, 981-1048. In: P. Castro, P.J.P. Davie, D. Guinot, F.R. Schram and J.C. von Vaupel Klein (Eds). The Crustacea, Treatise on Zoology - Anatomy, Taxonomy, Biology. Decapoda: Brachyura, 9 (Part C-II). Brill, Leiden- Boston, $1222 \mathrm{pp}$.

Clark, P.F., Calazans, D.D. and Pohle, G.W. (1998) Accuracy and standardization of Brachyuran larval descriptions.Invertebrate Reproduction and Development, 33 (2-3) : 127-144.

Fransozo, A.; Mantelatto, F.L.M. and Negreiros-Fransozo, M.L. (1991) Larval development of Hexapanopeus paulensis Rathbun, 1930 (Crustacea, Brachyura, Xanthidae) under laboratory conditions. Revista Brasileira de Zoologia, 7 (1-2): 31-45. 
Gohar, H. A. F. and Al-Kholy, A. A. (1957) The larvae of some brachyuran Crustacea. Publ. Mar. Biol. Stat. Ghardaqa, 9: 145-176.

Gurney, R. (1938) Notes on Decapod Crustacea from Red Sea: VI. VIII. Zool . Soc. Ser., B, 108: 73 - 84.

Ko, H.S. and Clark, P.F. (2002) The zoeal development of Nanocassiop granulipes (Saki, 1939)(Crustacea: Decapoda: Brachyura: Xanthidae) described from laboratory- reared material. Journal of Natureal History, 36:1463-1488.

Ko, H.S. and Lee, S.H. (2012) Invertebrate fauna of Korea, 21(22). Crabs and Zoeas II. Arthropoda: Malacostraca: Decapoda: Brachyura: Eriphioidea, Pilumnoidea, Xanthoidea. National Institute of Biological Resources, Incheon, pp. 1-93.

Lai, J. C.Y. ;Christopher, E. J. Danièle Guinot, M., Clark, P. F. and Ng, P.K.L. (2011) Xanthidae MacLeay, 1838 (Decapoda: Brachyura: Xanthoidea) systematics: A multigene approach with support from adult and zoeal morphology. Zoologischer Anzeiger, 250 : 407-448.

Lasley, R. M. Jr., Lai, J. C. Y and Thoma, B. P. (2013) A new genus for Chlorodiella longimana (H. Milne Edwards) supported by morphology and molecular data, with a preliminary phylogeny of the Chlorodiellinae (Crustacea: Decapoda: Xanthidae). Invertebrate Systematics, 27: 379-390.

Lasley, R.M. Jr., Klaus, S. and Ng, P.K.L. (2015) Phylogenetic relationships of the ubiquitous coral reef crab subfamily Chlorodiellinae (Decapoda, Brachyura, Xanthidae), Zoologica Scripta, 44: 165-178.

Martin, J.W.(1984) Notes and bibliography on the larvae of xanthid crabs, with a key to the known xanthid zoeae of the western Atlantic and Gulf of Mexico. Bull. Mar. Sci. 34 (2): 220-239.

Ng, P.K.L. and Clark, P.F.(2000) The Indo-Pacific Pilumnidae XII . On the familial placement of
Chlorodiella bidentata (Nobili, 1901) and Tanaocheles stenochilus Kropp, 1984, using adult and larval characters with the establishment of a new subfamily, Tanaochelinae (Crustacea: Decapoda: Brachyura). Journal of Natural History, 34 (2): 207-245.

Ng, R.K.L, Guinot, D. and Davie, RJ.R. (2008) Systema Brachyurorum: Part I . An annotated checklistof extant brachyuran crabs of the world . Raffles Bull. Zool . Supplement, 17: 1-286.

Prasad, R. R. and Tampi, P. R. S.(1957) Notes on some decapod larvae. J. Zool. Soc. India. 9: 22-29.

Rice, A. L. (1980) Crab zoeal morphology and its bearing on the classification of the Brachyura. Transactions of the Zoological Society of London, 35: 271-424.

Serène, R. (1984) Crustacés Décapodes Brachyoures de l'océan Indien occidental et de la mer Rouge. Xanthoidea: Xanthidae et Trapeziidae. Avec un addendum par A. Crosnier: Carpilidae et Menippidae. Faune Trop. 24: 1400 (pls. 1-48).

Tanaka, H. (1999) Zoeal development of the xanthid crab Zosimus aeneus (Linnaeus, 1758). Bulletin of Ibaraki Nature Museum, 2: 19-26.

Tanaka, H. and Konishi, K. (2001) Larval development of the poisonous crab Atergatis floridus (Linnaeus, 1767) (Crustacea, Decapoda, Xanthidae) decribed from laboratory-reared material. Crustaceanan Research, 30: $21-42$.

Tanaka, H. and Konishi, K. (2009) Atergatis floridus (Linnaeus, 1767) (Decapoda, Xanthidae) re-examination and correction of zoeal. Crustaceanan Research, 38: 5563.

Terada, M. (1982) Zoeal development of the chlorodinid crab, Pilodius nigrocrinitus Stimpson. Zoological Magazine, 91:23-28.

Vine, P. (1986) Red Sea Invertebrates. Immel Publishing, London. 224 pp. 
وصف الطور اليرقي الأول لنوع Heller, 1861) Luniella spinipes) من السرطانات قصيرة البطن

و المربى تحت ظروف المختبر والمجموع من وسط البحر الأحمر، السعودية العرية

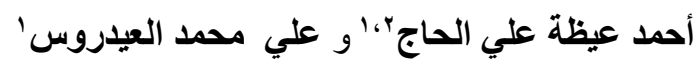

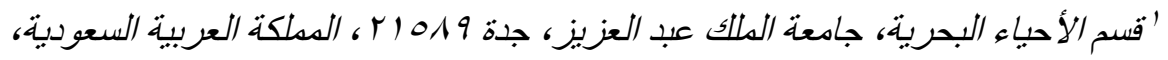

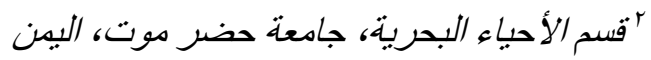

a302378@gmail.com

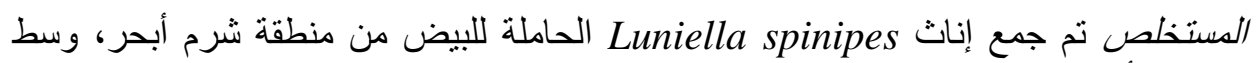

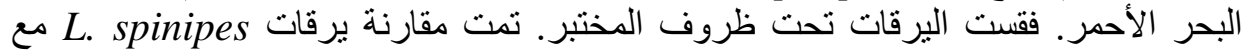

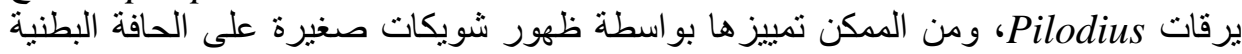

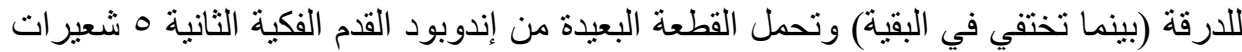

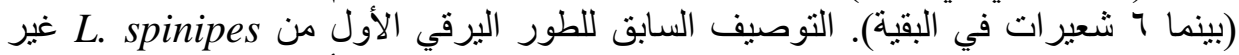

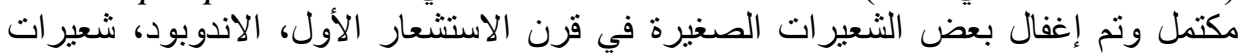

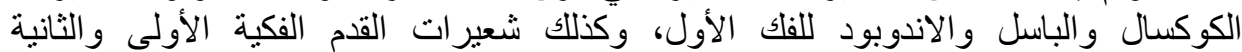

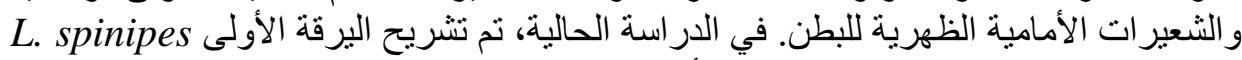

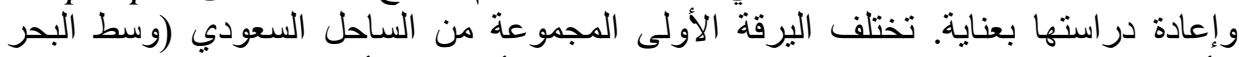

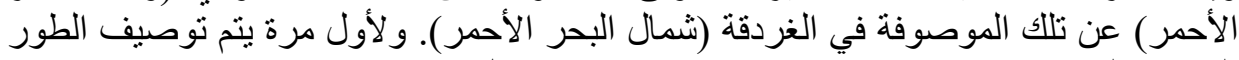

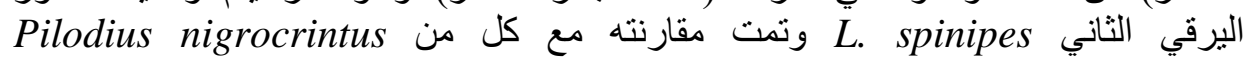
.Chlorodiella nigra,

الكلمات الدالة: Luniella spinipes, Pilodius، البحر الأحمر، الطور اليرقي الأول، الطور

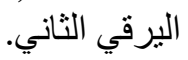

